\title{
Impact of Electricity Supply on the Performance of Small and Medium-Scale Enterprises (SMEs) in Nigeria: A Case Study
}

\author{
Akinyemi Alao Ajibola ${ }^{1}$, Gbemi Moses Sodeinde ${ }^{2}$, Timothy Ayomitunde \\ Aderemi $^{3 *}$, Modupe Ololade Yusuf ${ }^{4}$ \\ ${ }^{1}$ Department of Economics, Accounting and Finance, Bells University of Technology, km. 8, Idiroko \\ Road, Benja Village, P. M. B. 1015, Ota, Nigeria. \\ e-mail: aaajibola@bellsuniversity.edu.ng \\ ${ }^{2}$ Department of Business Entrepreneurship, Kwara State University, Malete, Nigeria. \\ e-mail:Merryshow11@yahoo.com \\ ${ }^{3}$ Department of Economics, Accounting and Finance, Bells University of Technology, km. 8, Idiroko \\ Road, Benja Village, P. M. B. 1015, Ota, Nigeria. \\ e-mail: aderemi. timothy@gmail.com \\ ${ }^{4}$ Department of Economics, Michael Otedaola College of Primary Education, KM. 7, Epe- Ijebu Ode \\ Road, Noforija-Epe, Lagos, Nigeria. \\ e-mail: modupeyusuf729@gmail.com
}

DOI: 10.51865/EITC.2021.04.02

\begin{abstract}
Despite the fact that past empirical studies have reported that numerous factors affect the performance of SMEs in Nigeria, yet power supply, which is the strategic driver of economic activities and its spillover effects on the performance of SMEs in Nigeria has not been fully investigated in the country. Against this backdrop, this study examined the impact of electricity on the performance of SMEs in Ado-Odo, Ota LGA, Ogun State. Consequently, the questionnaires were administered to the respondents using the method of purposive sampling. The data was analyzed using Statistical Package for Social Science (SPSS), variance analysis (ANOVA) and Correlations and Ordinary Least Squares (OLS) techniques. A total of 120 questionnaires were distributed, of which 90 were compiled and analyzed. The findings showed that there is significant impact of electricity supply on the performance of SMEs in Ado-Odo Ota Area, in Ogun State. Also, alternative power sources have significant impact on performance of SME in Ado-Odo Ota Area, in Ogun State. Therefore, by and large, from the findings of this study, the paper made the following recommendation for the policymakers and business owners in Ado-Odo, Ota Area of Ogun State in particular, and Nigeria by extension that sufficient supply of electricity should be placed in a place that maximizes the efficiency of small and medium-sized businesses. In the same vein, SMEs owners should strive to use alternative sources of power to boost the performance of SMEs, and meet their market objectives.
\end{abstract}

Keywords: electricity; supply; SME’s; performance; development.

JEL Classification: M20; M21; M13; Q20.

${ }^{*}$ Corresponding author 


\section{Introduction}

The role of SMEs is progressively significant in Nigeria, in the sense that through the SMEs available resources is developed for industrialization and consumption to increase the economic wellbeing of a nation. (Aderemi et al. 2020:1: Micah and Manzo, 2014). The importance of SMEs to economic development in a developing nation like Nigeria cannot be overemphasized because of its wide, different base and hastened effect towards attaining the macroeconomic objectives (income distribution, full employment and so on), makes its existence inevitable. (Aderemi et al. 2019: Ezema, 2014). In the same vein, it contributes directly to economic growth and livelihood in developing countries, because of its labour intensive mode of production, which leads to more equitable income distribution and boost employment. (Olowookere et al., 2021: Yaya, 2015). Consequently, in agro-based economies, livelihood opportunities are provided through simple, value adding processing which develops entrepreneurship. SMEs build a productive capacity that creates a resilient economy through the interconnections of small and large enterprises. In developing countries SMEs are the major economic force in which a large number of people rely on for their livelihood. (Adade, 2012).

Meanwhile, accessibility to constant and stable electricity is crucial to the performance of SMEs and economic growth (Bank, 2013; Aderemi et al., 2021), due to the fact that unreliable power supply can affect different aspect of business performance. Unexpected, usually prolonged, power outages can have debilitating impacts on the manufacturing process by halting productivity, causing damages to machineries, which in turn affects the overall business operation and the ability to ensure delivery times (World Bank, 2018). It has been argued that about $80 \%$ SMEs survive their first year contrast to most believe that most businesses crash within the first years. nevertheless, the number drops with time, only about Depending on the year the company started, 45.4 per cent to 51 per cent of small-businesses have survived the last five years. Also, only about 3 business survived for a period of 10 years (Chad, 2018).

However, past empirical studies have reported that numerous factors affect the performance of SMEs, such as financial constraint, poor personnel management, poor marketing, poor management and low entrepreneurial skill base, lack of infrastructure, unfavorable tariff policy and COVID 19 pandemic. See (Evbuomwan, Ikpi, Okoruwa and Akinyosoye, 2013; World Bank, 2014: World Bank, 2015: Aderemi et al. 2019; Aderemi et al. 2020:2). Whereas, power supply, which is a strategic driver of economic activities and its spillover effects on the performance of SMEs in Nigeria requires an urgent empirical investigation. Study regarding the impact of electricity on the performance of SMEs becomes inevitable because the available statistics shows that about 56. 5\% of Nigerians have access to electricity (World Bank, 2018). Therefore, the need for a reliable power supply is an important factor that could reduce the cost of production by SMEs.

In spite of the changes in the Nigeria electricity sector, electricity supply is still poor and about 80 million Nigerians living in the 774 local government areas over the country lack access to electricity $43.5 \%$ of the population lack access to power (World Bank, 2017). Electricity in respect to consumption is divided into residential, commercial and industrial and this different consumption impacts the economy differently, Nigeria is characterized by large informal sector where SMEs activities occurs, in this informal sector it is therefore crucial to investigate the significance of electricity (Ajibola, 2016). The country has been making use of about 2,500 to 4,000 megawatts and this has an adverse effect on manufacturing sectors, investments are lost as a result of deficient power supply and because of this Nigeria may continue to lose investors to other African countries. Similarly, MAN also stated that many companies and small enterprises are closing down and relocating to Ghana, where adequate electricity exists. Since the manufacturing sector is the major employer of Labour, the problem of electricity has to be resolved since a business cannot successfully run without regular electricity supply (MAN, 
2019). In the light of the above, this research therefore attempts to study the effect of electricity supply on the productivity of SMEs in Nigeria using Ado-Odo Ota LGA, Ogun-State as a case study. This choice of this area of study is motivated due to the fact this area constitutes one the largest industrial hubs in Nigeria.

Moreover, in other to provide empirical evidence in this study, the study raised the following research questions. What is the effect of the production of electricity on the output of small \& medium businesses in Ado-Odo Ota LGA, Ogun-State? How does alternative power affect the performance of SMEs in Ado-Odo Ota LGA, Ogun State? In the same vein, the study addressed these objectives. Examined the impact of electricity supply on SMEs performance in Ado-Odo Ota LGA, Ogun State, and how alternative power affects the performance of SMEs in Ado-Odo Ota LGA, Ogun State.

\section{Literature Review}

\section{Conceptual Review}

\section{Small \& Medium Sized Enterprises}

SMEs are small independent firms that employ few numbers of employees. There is no generally acceptable definition of SMEs. Different definitions cut across number of employees, capital or size of business and revenue, and these definitions varies across countries. European Union defines a medium size enterprise as "one with less than 250 employees with a final ceiling of EUR 50 million and a small firm as one with less than 50 employees with a financial ceiling of EUR 10 million" (European-Union, 2003). In the United States SMEs are firms with employees fewer than 500. Japan defined SMEs into 3 segments; those in manufacturing wholesale and retail. Manufacturing with less than $¥ 300 \mathrm{~m}$ (US\$3. 6m) in capital, wholesale trade with less than $¥ 100 \mathrm{~m}$ (US\$1.2m) in capital, and those in the retail and service trades with less than $¥ 50 \mathrm{~m}$ (US\$600,000) in Capital.

In its Monetary Policy Circular No. 22 of 1988, the Central Bank of Nigeria (CBN) described SMEs as an undertaking with less than 500,000 naira as its annual turnover. In the 1990 budget for commercial bank loans, the federal government described small and medium-sized enterprises as having an annual turnover of less than 500,000 naira, in the case of merchant bank loans, as having a capital expenditure not exceeding 2 million Naira (excluding land costs) /a maximum of 5 million naira. Recent Definition of SME by Financial system strategy defined SMEs as an enterprise having an annual turnover of less than 100million naira/ or less than 300 employees (Banji, 2020).

\section{Electricity}

Energy is defined as the capacity to producing heat or doing work. Heat is usually acquired by capturing sun rays, fuel burning, rocks below earth surface or by other means. The ability to do work may represent the capability (or potential) of doing work, its manifestation in terms of conversion to motive power (known as kinetic energy). Electricity supply can be divided into three stages; generation, transmission, distribution. There's also a commercial which involves the retail aspects of trading electricity to a wide range of users.

Generation: The generation of electricity is mostly done in large scale from a broad range of natural resources such as hydro, gas and coal at conventional power station or from a renewable energy farm. Generators may compete to sell their products into a pool such as the National Electricity Market in much of Australia in the eastern and southern states or the wholesale electricity market in Western Australia, which is controlled by an independent market operator. Distributed generations are increasingly used within networks, these generators are factory- 
based cogeneration plants that generate solar installations, coal seam methane installations associated with coal mines, wind farm \& biogas (Energy Networks Association Limited, 2008).

\section{Electricity effect on SME's performance}

Several studies have been made by previous researchers to ascertain the impact of electricity on SMEs performance. The performance could include financial and non-financial. Financial performance could include return on sales, return on assets, current ratio, equity etc. Previous studies outcomes showed mainly two type of relationship exist between electricity supply and SMEs performance that is; a positive relationship or a negative relationship.

\section{Empirical review}

Tahir and Inuwa (2019) used primary data analysis to investigate the factors affecting SME's performance in Maiduguri, Borno State, Nigeria. In order to analyze the data obtained, descriptive \& inferential statistics, correlation \& multiple regression analysis revealed that poverty and insufficient infrastructure facilities are the most critical factors influencing the success of SMEs in Borno-State. It has been proposed that valuable facilities \& security should be implemented to enhance the efficiency of SMEs.

Akinlemi (2018) examined the effect of infrastructural facilities on SME's growth in Nigeria. Primary data was employed, Chi-square was employed for hypothesis testing, result obtained showed that many SME's in Nigeria provide basic infrastructure themselves and the cost of providing this basic infrastructure is huge which cost many SME's operators to run out of business. It was recommended that government should provide a basic infrastructural facility to grow SMEs which in turn increases the country's GDP.

The effect of electricity service efficiency on the performance of manufacturing SMEs in Nigeria was checked by Abdulrahim, Issa and Ismaila (2017). 201 survey questionnaires were used by participants of the output association MAN, SPSS, as well as basic regression analysis, was performed. The result shows that more than 50 per cent of the difference in the financial and non-financial output of manufacturing SMEs in Nigeria appears to account for consistency. To remove bias linked to time, it was proposed that future studies should collect panel data/longitudinal data.

Akinyele, Akinyele, and Ajagunna (2016) in an examination of infrastructural development as a predictor to SMEs performance in Ogun state through a survey design and ANOVA on 239 small and medium scale enterprises found the correlation between infrastructure and SME's performance to be positively significant. The study therefore recommended that government should put in place enough infrastructures for SME's, because SMEs cannot by themselves provide the resource they need. SME's should also do more to attract the government's interest and attention.

Bako et al. (2021) investigated how microfinance credit contributed to the development of some selected Small and Medium Enterprises focusing on some essentials amidst COVID-19 pandemic using Sango-Ota industrial estate of Ogun state, Nigeria as the case study. The authors reported that more than $90 \%$ of enterprises utilized microfinance credit for their businesses during the pandemic. And micro credit led to a rise in the stock of goods in these selected enterprises, which resulted in a moderate rise in profit of the majority of the SMEs selected for the survey.

Ogunleye et al. (2020) employed ARDL-Bounds test and Error Correction in the estimation of the between SMEs financing and poverty reduction in the Nigerian economy ranging between 1990 and 2018. The authors opined that both in the short run and the long run, the financing of manufacturing and food processing businesses sponsored poverty reduction in the country. Using secondary evidence, Ologundudu (2015) analyzed the effect of electricity supply on 
industrial \& economic growth in Nigeria, researched the causal \& long-term relationship between the supply of electricity, industrialization and economic growth in Nigeria from 1972 to 2010, The analytical research was performed using the co-integrated ARDL boundary test method and the granger and causality test was also used. The outcome showed that a one-way relationship is a relationship between capital employed and GDP, energy and money, labour and electricity. A causal relationship between GDP per capita \& power supply was also seen in the outcome. In order to direct economic growth by industrialization, it was resolved that the power issue should be solved.

\section{Methodology}

The study focuses on Ado- Odo Ota, Ogun state and upon the subject of the study which is the impact of electricity supply on the performance of SMEs. This choice of this area of study is motivated due to the fact this area constitutes one the largest industrial hubs in Nigeria. This study is limited to the Sango Ota industrial area as a result of lack of funds, and COVID-19 restrictions. Consequently, the study adopted survey research design. Survey research is collection of data via analysis of a group of people that are considered to be a representative of the entire group or population (Asika, 2012). Thus, the researchers collected data from the owners and managers of SMEs in Sango Ota forming the study population.

\section{Sample Size and Sampling Techniques}

The sampling procedure that was adopted for this research was the purposive sampling. This method allows the researcher to select respondents (samples) that are available and ready to participate in the study among the entire population. That way, reduced to the barest minimum if not eliminated unwilling attitude of respondents. Thus one hundred and twenty (120) owners and managers of SMEs' in Ogun-state were selected for the study.

\section{Sources of Data}

This study utilized primary data via the usage of a closed ended questionnaire from primary sources: The data gathered from this source include the one obtained as a result of direct contact with the selected owners and managers of SMEs in Ado-Odo, Ota Ogun state which include questionnaire administered to the respondents.

\section{Model Specification}

The model expresses the relationship between electricity supply and SME's performance in Nigeria. The importance of this model is to show the validity of the model specified in this research. The model of this research work is as formulated below;

$$
\begin{gathered}
\text { SMEs Performance }=\mathrm{f}(\text { Electricity Supply }) \\
\text { SMET }=\mathrm{f}(\text { SEC }, \text { SCAPS })
\end{gathered}
$$

Where:

SMET is used to proxy SMEs performance in Nigeria which is measured by SMEs Turnover. SEC denotes SMEs' Electricity Consumption and SCAPS represents SMEs' Cost of Alternative Power Supply. Therefore, in addressing the impact of electricity supply and alternative power supply on SMEs performance in Ado-Odo Ota LGA, Ogun State, the model to achieve this is specified as follows:

$$
\mathrm{SMET}=\beta_{\mathrm{o}}+\beta_{1} \mathrm{EC}+\beta_{2} \mathrm{CAPS}+\mathrm{u}
$$


$\mathrm{B}_{0}=$ Intercept of the model and $\mathrm{B}_{1}, \beta_{2}=$ Coefficients of the parameters. $\mathrm{u}$ is error term, which represents other factors that affect the independent variable outside the model. It is expected that $\beta_{2}$ and $\beta_{2}>0$.

\section{Research Hypothesis}

$\mathrm{H}_{0}$ : Electricity supply does not have a significant impact on the performance of SMEs in AdoOdo Ota LGA, Ogun State.

$\mathrm{H}_{1}$ : Electricity supply has a significant impact on the performance of SMEs in Ado-Odo Ota LGA, Ogun State.

\section{Data Presentation, Analysis and Discussion of findings}

In addressing the objectives of this study, the study made use of Statistical Package for Social Science software version 25 for data analysis. The data analysis was done using simple percentage, frequency tables, correlation, ANOVA, Ordinary Least Squares, descriptive and inferential charts, and Pearson Correlation statistical tool.

\section{Questionnaire response rate}

The questionnaire response rate (completion rate) refers to the number of questionnaires retrieved from the respondents divided by the total number of questionnaires administered to respondents. This was expressed in the form of a percentage.

Out of the 120 questionnaires administered to the Small and Medium Scale Enterprises in Ado Odo, Ota LGA. 90 questionnaires were retrieved from the respondents and 30 questionnaires were not returned. Therefore, $75 \%$ of the questionnaires were returned, while $25 \%$ of the questionnaires were not retrieved. Therefore, the response rate obtained in the study was considered good as shown in Table 1:

Table 1. Questionnaire response rate

\begin{tabular}{|c|c|c|}
\hline Response Rate & Sample Size & Percentage (\%) \\
\hline Returned Questionnaires & 90 & 75 \\
\hline Un-returned Questionnaires & 30 & 25 \\
\hline Total & $\mathbf{1 2 0}$ & $\mathbf{1 0 0}$ \\
\hline
\end{tabular}

Source: Survey, 2021.

\section{Demographic information}

Based on the unit analysis of the study, the demographic information considered necessary are the gender, marital status, age range, highest educational level, business position and years of business existence of respondents in the organization are shown in Table 2.

Table 2, is a presentation of the demographic characteristic respondents who partook in the study, whose outcomes were presented in a tabular representation using frequencies and percentages. As illustrated in Table 4. 1. 2 Show the gender distribution of the respondents, where male respondent was $62.2 \%$ and female respondent was $37.8 \%$. Most respondents were male. By implications, gender distribution respondents were evenly distributed. 
Table 2. Socio-demographic characteristics of the respondents

\begin{tabular}{|c|c|c|}
\hline Socio-Demographic Characteristics & Frequency & Percent \\
\hline \multicolumn{3}{|l|}{ Gender } \\
\hline Male & 56 & 62.2 \\
\hline Female & 34 & 37.8 \\
\hline Total & 90 & 100 \\
\hline \multicolumn{3}{|l|}{ Marital Status } \\
\hline Single & 21 & 23.3 \\
\hline Married & 67 & 74.4 \\
\hline Divorced & 1 & 1.1 \\
\hline Widow/Widower & 1 & 1. 1 \\
\hline Total & 90 & 100 \\
\hline \multicolumn{3}{|l|}{ Age Range } \\
\hline Below 25 years & 8 & 8.9 \\
\hline $26-35$ years & 17 & 18.9 \\
\hline $36-45$ years & 35 & 38.9 \\
\hline 46 years and above & 30 & 33.3 \\
\hline Total & 90 & 100.0 \\
\hline \multicolumn{3}{|l|}{ Highest Educational Qualification } \\
\hline Primary Leaving Certificate/WAEC & 5 & 5.6 \\
\hline $\mathrm{NCE} / \mathrm{ND}$ & 11 & 12.2 \\
\hline $\mathrm{HND} / \mathrm{BSc}$ & 65 & 72.2 \\
\hline $\mathrm{MSc} / \mathrm{MBA} / \mathrm{MA}$ & 9 & 10.0 \\
\hline Total & 90 & 100.0 \\
\hline \multicolumn{3}{|l|}{ Position in Business } \\
\hline Sole Owner & 61 & 67.8 \\
\hline Partner & 17 & 18.9 \\
\hline Finance Manager & 3 & 3.3 \\
\hline
\end{tabular}

Source: Survey, 2021. 


\section{Relationship between electricity supply and SME's performance in Nigeria.}

The results in Table 3 show that a positive relationship existed between electricity supply and SME performance. A unit change in electricity supply leads to about 3. 9\% increment in the performance of the selected SMEs in Sango-Ota, Nigeria. In the same vein, the alternative power source and the performance of SME had a positive relationship with the performance of SMEs in the studied area. A unit change in the alternative power source causes about 3. 7\% rise in the performance of SMEs in studied area. Meanwhile, $\mathrm{R}^{2}$ indicates that $72 \%$ of the variation in SME performance was explained by electricity consumption and alternative power supply while $28 \%$ was left unexplained in the model due to random chance. This is an implication that the model is relatively good for the analysis.

Table 3. Method: Ordinary Least Squares - OLS

\begin{tabular}{|l|c|c|c|c|c|c|l|}
\hline SMET & constant & gradient & SEC & SCAPS & $\mathrm{R}^{2}$ & Adjusted $\mathrm{R}^{2}$ & F-statistics \\
\hline SEC & 3.545 & .439 & 3.984 & 3.690 & 0.725 & 0.725 & $\begin{array}{l}235.296 \\
(0.000)\end{array}$ \\
\hline
\end{tabular}

Source: Authors`computation, 2021.

\section{Significance of relationship between electricity supply and SME's performance in Nigeria}

In testing the significance or otherwise of relationship between electricity supply and SME's performance in Nigeria, two hypotheses were as follows;

\section{Hypothesis 1:}

$\mathrm{H}_{\mathrm{o}}$ : Electricity supply doesn't have any significant impact on the performance of SMEs in AdoOdo Ota LGA, Ogun-State.

$\mathrm{H}_{1}$ : Electricity supply does have significant impact on the performance of SMEs in Ado Odo Ota LGA, Ogun-State.

From Table 4, the ANOVA output shows that the null $\left(\mathrm{H}_{0}\right)$ hypothesis of there is no significant relationship between the dependent variable (performance of SME) and the independent variable (Electricity Supply) was rejected because R2 $=0$, with the value of $F=235.296$ and 89 degrees of freedom, and a corresponding $\mathrm{P}$ value of 0 . 000. And the alternative $\left(\mathrm{H}_{1}\right)$ hypothesis is accepted. Hence there exists a significant linear relationship between the supply of electricity and SME performance in Sango-Ota.

Table 4. Hypothesis Testing

ANOVA $^{\mathrm{a}}$

\begin{tabular}{|l|l|l|l|l|l|}
\hline Model & $\begin{array}{l}\text { Sum of } \\
\text { Squares }\end{array}$ & df & Mean Squares & F & Sig. \\
\hline Regression & 306.130 & 1 & 306.130 & 235.296 & $.000^{\mathrm{b}}$ \\
Residual & 114.492 & 88 & 1.301 & & \\
Total & 420.622 & 89 & & & \\
\hline
\end{tabular}

a. Dependent variable: Performance of SMEs

b. Predictors: (Constant), Electricity Supply

Source: Authors`computation, 2021.

\section{Discussion of Findings, Conclusion and Policy Recommendation}

From the result, the findings have shown that there is significant impact of electricity supply on the performance of SMEs. In light of the above therefore, some interpretation can be made. This 
indicates that for any increase in electricity supply would lead to an increase in the performance of SMEs. Also, alternative power sources has significant impact on performance of SME in Ado-Odo Ota Area, in Ogun State. This finding was supported by Andrew, Emily, Alberto and Juan, (2014) maintain that many firms have lowered productivity because of power outage experience compared to firms which do not. Furthermore, alternative power source contributed a positive effect to the performance of SMEs Ado Odo Ota LGA, Ogun State. This finding is in tandem with the submission of Nyanzu (2016) who posited that SMEs should consider the usage of alternate power such as generators, biogas, solar power and inverters which would help in controlling of electricity outages and boost output.

Therefore, by and large, from the findings of this study, the paper made the following recommendation for the policymakers and business owners in Ado-Odo, Ota Area of Ogun State in particular, and Nigeria by extension that sufficient supply of electricity should be placed in a place that maximizes the efficiency of small and medium-sized businesses. In the same vein, SMEs owners should strive to use alternative sources of power to boost the performance of SMEs, and meet their market objectives.

\section{References}

1. Abdulrahim, M., Issa, A. and Ismaila, Y., 2017. Impact of Electricity Service Quality on the Performance of Manufacturing SMEs in Nigeria. Journal of Business and Social Review in Engineering Economies, 3(1), 1-10.

2. Adade, T. C., Ahiawodzi, A. K., 2012. Access to credit and growth of small and medium. British Journal of Economics, Finance and Management Sciences, 6(2), 34-51.

3. Aderemi, T. A., Tolulope, A. C., Adedayo, A. and Arinola, B. L., 2019. Entrepreneurship Financing and Nation Building in Nigeria: Evidence from Agricultural Small and Medium Scale Enterprises. Management Studies and Economic Systems, 4(4), 315-330.

4. Aderemi, T. A., Efunbajo, S. A., Amusa, B. O. and Rasheed, O. I., 2020: 1. Does Entrepreneurship Financing Contribute To Poverty Eradication In Nigeria? Evidence from Small and Medium Scale Enterprises. Journal of Academic Research in Economics, 12(2), 312-322.

5. Aderemi, T. A., Lucas, B. O., Okoh, J. I. and Efunbajo, S. A., 2020: 2. Impact of Corona Virus (COVID-19) Pandemic on Small and Medium Scale Enterprises (SMEs) in Nigeria: A Critical Case Study. ACTA Universitatis Danubius, 16(4), 251-261.

6. Aderemi T. A., Oyegoke A. A., Wahid D. O., Olaoye O. P, Ayodeji, G. B. and Azuh, D. E., 2021. Human Capital Development, Energy Consumption and Crude Oil Exports in Nigeria: Implications for Sustainable Development. International Journal of Energy Economics and Policy, 11(4), 443449

7. Ajibola, A. A, 2016. Residential and Industrial Electricity Consumption Dynamics and Economic Growth in Nigeria from 1980-2010. International Journal of Economy, Energy and Environment, $1(3), 55-63$.

8. Akinlemi, O. A., 2018. The Effect of Infrastructural Facilities on SMEs Growth in Nigeria. International Journal of Innovation Research and Development, 7(6), 196-203.

9. Akinyele, S. T., Akinyele, F. E. and Ajagunna, O. D., 2016. Infrastructural Development as Predictor to SMEs Performance in Nigeria. Kuwait chapter of Arabian Journal of Business and Management Review, 6(3), 40-53.

10. Andrew, S., Emily, D., Alberto, L. and Juan, R., 2014. The Effect of Electricity Insecurity on Businesses in Low and Middle Income Countries? London: Overseas Development Institute.

11. Asika, N., 2012. Research Methodology in Behavioral Sciences. Longman Nigeria Plc.

12. Bako, Y. A., Oyegoke, A. A., Idowu, A. F. and Aderemi, T. A., 2021. Microfinance Banks, Small and Medium Scale Enterprises and COVID-19 Pandemic in Nigeria. European Journal of Economics, Law and Politics, 8(2), 1-10.

13. Banji, O. O., 2020. SME: Issues, Challenges and Prospects. FSS 2020 international conference.

14. Bank, W., 2013. Enterprises Survey in Nigeria.

15. Chad, O., 2018. Forbes (October 25) Retrieved from Forbes Finance Council: https://www. forbes. com/sites/forbes-personal-shopper/2020/09/10/best-kitchen-scales according-toexperts/\#5c4c5a122060 
16. Energy Networks Association Limited, 2008. ENA Customer Guide to Electricity Supply. Level 3, 40 Blackall Street, Barton, ACT 2600: Energy Networks Association.

17. European Union, 2003. Eurostat. Retrieved from Small and Medium Sized Enterprises: https://ec. europa. eu/eurostat/en/web/structural-business-statistics/sme

18. Evbuomwan, G. O., Ikpi, A. E., Okoruwa, V. O. and Akinyosoye, V. O., 2013. Sources of finance for micro, small and medium enterprises in Nigeria. Paper presented at the 19th International Farm Management Congress, SGGW, Warsaw, Poland.

19. Ezema, M. C., 2014. Small And Medium Scale Enterprises in Nigeria: Problems And Prospect.

20. MAN, 2019. Energy Mix Report. June 7. Retrieved from MAN says poor power supply affecting investments in Nigeria's manufacturing sector: https://www. energymixreport. com/man-says poorpower-supply-affecting-investments-in-nigerias-manufacturing-sector/

21. Micah, D. J. and Manzo, A., 2014. The role of small scale business in poverty alleviation: The gains for industrial development in Nigeria. In David, O. I. and Urin, U. M (eds. ). Trajectory to Industrial Development in Nigeria. Covenant University, Ota Ogun State Nigeria. A publication of Department of Sociology Covenant University, Canaanland, Ota; 2014

22. Ogunleye, A. G., Aderibigbe, E. A., Lucas B. O, Ishola, J. A. and Aderemi, T. A., 2020. Reinvestigating Entrepreneurship Financing and Poverty Eradication in Nigeria: Any Difference from the Case of Small and Medium Scale Enterprises? Journal of Management and Accounting, $10(3), 77-89$.

23. Olowookere, J. K., Hassan, A. O., Adewole, A. O. and Aderemi, T. A., 2021. Small and Medium Scale Enterprises (SMEs) Financing and Sustainable Economic Growth in Nigeria. The Journal of Accounting and Management, 11(1), 220-228

24. World Bank Report, 2015. World Bank Estimates, Washington DC.

25. World Bank Enterprise Survey, 2014.

26. World Bank, 2018. World Development Indicators. Washington D. C. Available through http://data. worldbank. org/data-catalog/world-developmentindicators. [ Accesed 11 August 2018].

27. Yahaya, Y, 2015. Financing Small and Medium-Scale Enterprises for Sustainable Growth and Development in Nigeria: A Case Study of Zaria, Kaduna State. Journal of Economics and Sustainable Development, 6(14), 137-142.

28. Adebiyi, A. J., Hassan, A. B. and Oko-Oza, O. R., 2017. Performance of Small and Medium Enterprises in Lagos State: The Implications of Finance. Acta Universitatis Danubius. (Economica), 13(5), 1-11.

29. Agwu, M. O., 2014. Issues, Challengesand Prospectsof Small and Medium Scale Enterprises (SMEs) in Port-Harcourt City, Nigeria. European Journal of Sustainable Development, 3(1), 101 114.

30. Ajibade, A. T., Abdulraheem, I. and Mordi, C., 2014. The Characteristics and Challenges of Small Businesses in Africa: an Exploratory Study of Nigerian Small Business Owners . Economic Insights - Trends and Challenges, 3(4), 1-14.

31. Akinbola, O. A., Zekeri, A. and Idowu, H. A., 2017. The Power Sector And Its Impacts On Industrialization Of Businesses In Nigeria. Archives of Business Research, 12(5), 294-305.

32. Akuru, U. B., Okoro, O. I., 2014. Economic Implications of Constant Power Outages on SMEs in Nigeria. Journal of Energy in southern Africa, 25(3), 61-66.

33. Dabor, A. O. and Oserogbo, A., 2017. Challenges Facing Small And Medium Scale Enterprises In Nigeria. International Journal of Marketing \& Financial Management, 5(5), 52-65.

34. Dictionary, 2020. Dictionary.com. Available through: Dictionary.com: https://www. dictionary. $\mathrm{com} /[$ Accessed September 14].

35. Doe, F. and Asamoah E. S., 2014. The Effect of Electric Power Fluctuations on the Profitability and Competitiveness of SMEs: A Study of SMEs within the Accra Business District of Ghana. Journal of Competitiveness, 6(3), 32-48.

36. Fatoki, O. and Garwe, D., 2010. Obstacles To The Growth Of New SMEs In South Africa: A Principal Component Analysis Approach. African Journal of Business Management, Vol. 4(5), 729738.

37. Forkuoh, S. K. and Yao, L., 2015. Electricity Power Insecurity and SMEs Growth: A Case Study of the Cold Store Operators in the Asafo Market Area of the Kumasi Metro in Ghana. Open Journal of Business and Management, 312-325.

38. Foster, V. A., 2009. Paying The Price For Unrealiable Power supplies; In-House Generation Of Electricity By Firms In Africa. 
39. Grimma, M., Hartwig, R. and Layd, J., 2013. Electricity Access and the Performance of Micro and Small Enterprises: Evidence from West Africa. European Journal of Development Research, 25(5), 815- 829.

40. Hassan, O. G. and Afrah, N. A., 2017. Lack of Infrastructure: The Impact on Economic Development as a case of Benadir region and Hir-shabelle, Somalia. Developing Country Studies, 7(1), 49-55.

41. Henry, J. T., Asor, A. E. and Ndiyo, N., 2016. Impact of Power Sector Reforms on Small Scale Businesses in Cross River State, Nigeria. Global Advanced Research Journal of Economics, Accounting and Finance, 4(2), 15-23.

42. Ketelhod, A. V. and Wöcke, A., 2008. The Impact Of Electricity Crises On The Consumption Behaviour Of Small And Medium Enterprises. Journal of Energy in Southern Africa, 19(1), 4-12.

43. Lassana, C. and Abdoulaye, S., 2013. Electrical Power Outages And Productivity Of Small And Medium Enterprises In Senegal. Investment Climate and Business Environment Research Fund, 77(13), 2- 28.

44. Marlow, S., 2005. Labour management in small firms. London: Routhledge.

45. Mbugua. S. K., Njeru. A. and Ondabu, I. T., 2014. Factors Affecting the Performance of Small and Micro Enterprises in Limuru Town Market of Kiambu County, Kenya. International Journal of Scientific and Research Publications, 4(12), 1-20.

46. Menna, A. A., 2013. Factors Affecting The Performance Of Small And Medium Enterprises (SMES) In The Manufacturing Sector Of Cairo, Egypt. International Journal of Business And Management Studies, 5(2), 157-166.

47. Modi, A. and Adamu, J., 2016. Impact Of Power (Electricity) Supply On The performance of small and Medium Scale Enterprises In Adamawa State: Case Study Mubi North Local Government Area. International Journal of Humanities and Social Science Research, 2(12), 4-13. 